that can be used to help others take decisions. Our role is not to cast shadows or to mediate those decisions. This chapter also makes clear what is possible and what, at the moment, is a utopia.

Coming to Life is said to be aimed at "those who are curious and who would like to understand the process of life a little better without having to deal with highly specialized knowledge". The final chapter in particular makes

\title{
Charting an Arabic course
}

\section{Mathematical Geography and Cartography \\ in Islam and their Continuation in the Occident, Vol. I. Historical Presentation by Fuat Sezgin, transl. Guy Moore \& Geoff Sammon \\ Institut für Geschichte der Arabisch- Islamischen Wissenschaften, Johann Wolfgang Goethe-Universitāt: 2005. 636 pp. $€ 175$}

\section{A. M. Celâl Șengör}

Few books in the historiography of science have single-handedly created a revolution in their subject, but this one just might. It is the result of a 15-year effort by the renowned Arabist and science historian Fuat Sezgin. Originally, the book was to be just another volume in the author's History of Arabic Literature series, begun in 1967 , in which a scholarly historical introduction is followed by a list of authors and critical assessments of their works. Mathematical Geography and Cartography in Islam and their Continuation in the Occident retains this format, but the usual introduction is expanded into two massive volumes of 'historical presentation', plus a lavishly illustrated atlas with 209 maps (many in colour). It was originally published in German in 2000, but an English translation of Volume 1 is now available and Volume 2 will follow shortly, along with the final 'authors' section of the German original.

While working on the book, Sezgin found that conventional treatments of the history of mathematical geography and cartography had failed to take into account nearly half of the available material, and it is the narration and analysis of this that fills the bulk of these volumes. He first became aware that something was seriously amiss when he heard about the sudden appearance of some portolan maps, or navigational sea charts, from around 1300 , and some remarkably accurate longitude and latitude data in European maps of parts of Asia, dating from times when no European had been there to take any measurements.

A clue to the puzzle lay in the discovery of an annotated version of Masalik al-abşar $f i$ mamalik al-amşar by Ibn Fadlallah al-Umari, a representation from 1340 of a lost map of the world prepared by the geographers of one wonder whether reading this book would not also benefit politicians, social activists and journalists who ponder issues such as cloning and stem-cell or genetic therapies in the public realm. They might find the science rather challenging in places, but it would certainly give them a perspective for their judgements. Alfonso Martinez Arias is in the Department of Genetics, University of Cambridge, Cambridge CB2 3EH, UK. the Abbasid caliph al-Ma'mun in the eighth century. The version by al-Umari was drawn on a pre-existing graticule with a globular projection, and not vice versa as had previously been assumed - I can vouch for this, having checked the original myself. This helped Sezgin interpret the data on geographical coordinates that originally accompanied the Ma'munic map. Sezgin found the data preserved in the book Surat al-ard from the early ninth century, which has commonly, but mistakenly, been considered to be an original work of Abu Ja'far al-Khwârizmi. It is now thought to be a simple register of Ma'munic location data.

Sezgin argues that the collection of all these data necessitated new fieldwork and must have required a large group of observers, rather than being revisions by one hypothetical Syriac author of a Ptolemy translation, as Hans von Mzik had proposed. Sezgin's reconstruction of the Ma'munic map, put together using the only two preserved versions of its coordinate data, shows that the Ma'munic geographers had reverted to the earlier idea, proposed by the Greek scholar Eratosthenes, that the world consisted of inhabited land surrounded by the ocean, as opposed to Ptolemy's view in which oceans appeared as giant lakes. For example, the map shows the Arabic error of considering the Malaysian peninsula to be a vast elongation of southern China, but separated from Africa, as seen in al-Umari's map. An even older version of the map discovered by Joseph Needham corroborates Sezgin's reconstruction.

Once the Mamunic improvement on Ptolemy was correctly reconstructed, it led to a search for other geodetic improvements, both in methods and in results, by Islamic mathematical geographers and cartographers. Sezgin documents in great detail how the Ptolemaic long Mediterranean' was shortened almost to its length today by fixing the positions of Baghdad and Toledo; how the Caspian Sea gradually acquired its correct outlines; how, by a combination of dead reckoning and trigonometry, the Arabs managed to get to grips with longitude at sea; and finally, how the distance between Ghazna and Baghdad was measured with astonishing precision in the eleventh century using astronomical observations and spherical trigonometry.

Sezgin then documents the influence of these achievements in Europe. A number of Western authors, including Marco Polo, Dante, the astronomer Johannes Kepler and the cartographer Nicolas Sanson, seem to have been informed by Arabic-Islamic geography. Sezgin shows how the Muslim maps led to the portolans, as they had to Portuguese maps of the Indian Ocean. He documents and discusses in great detail the information that Muslim geographers gathered on Asia, the

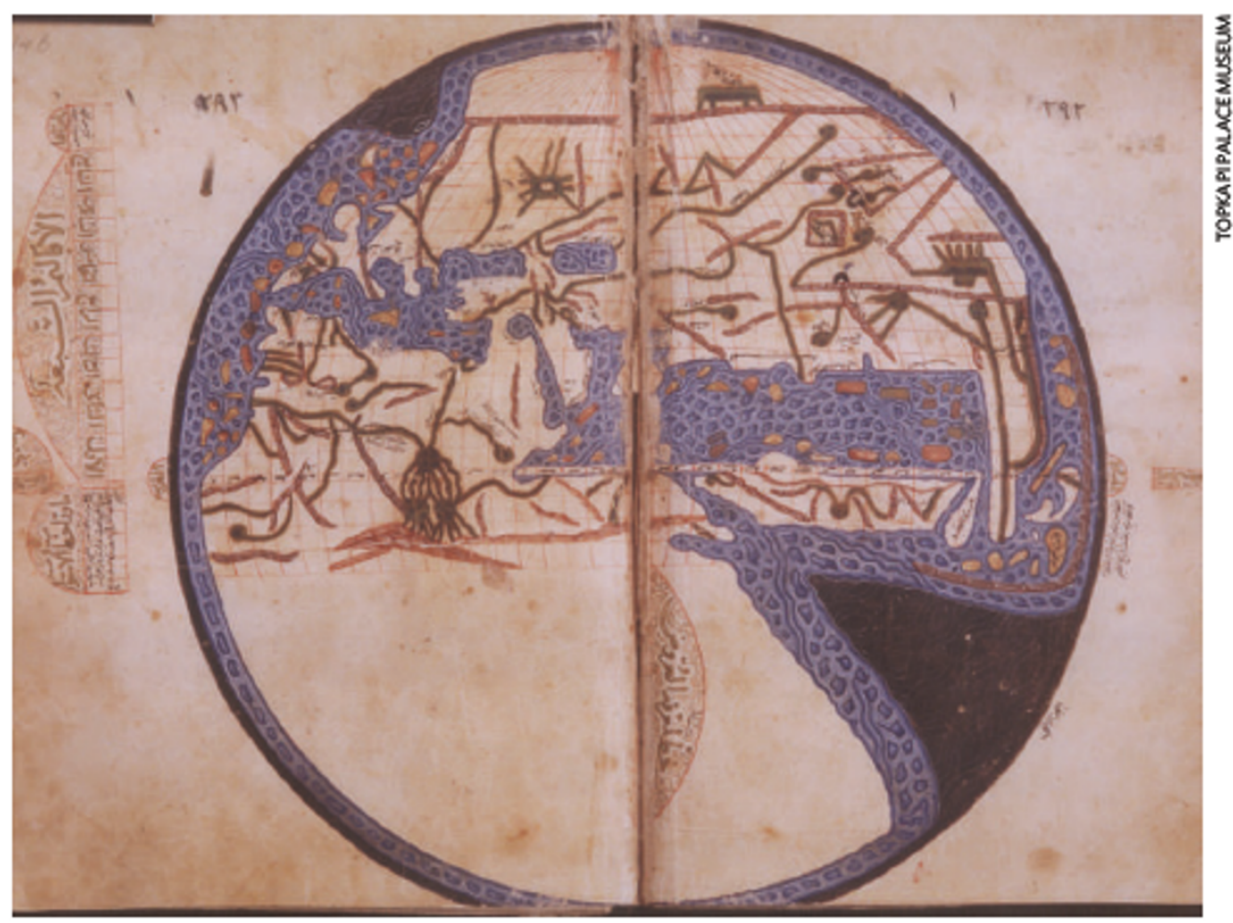

An Arabic world view: Ibn Fadlallah al-Umari's map from 1340 contains data from the eighth century. 
Indian Ocean, the Malay Archipelago, the Mediterranean and Africa. He also details the new geodetic methods they discovered and the numerous coordinate tables they generated, which influenced European maps well into the eighteenth century.
The abundance of material brought together in this book is truly awesome. The three handsomely produced volumes are thoroughly indexed. With so many novelties, Sezgin's book will no doubt be controversial. But therein lies an added value: it will provoke an even more thorough search for additional data on the history of a subject that had long stagnated. A. M. Celal Șengorr is in the Department of Geology, Istanbul Technical University, and the Eurasian Institute of Earth Sciences, Ayazaga, 34469 Istanbul, Turkey.

THEATRE

\section{Would the real Mr Feynman...?}

\section{Clever Dick}

written and directed by Crispin Whittell

At Hampstead Theatre, London, until 17 June

www.hampsteadtheatre.com

\section{Richard Webb}

"Confusion. See, confusion ain't a sickness I suffer from. I take my strength from the simple love of my country and faith in my God." Self-doubt does not cloud the horizons of 'Fat Man' Sergeant Whitey Stokes, CounterIntelligence Corps, on the evening of 17 June 1945. The Red spy he thinks he's interrogating - the physicist Richard Feynman - on the other hand, is very confused. He hasn't slept for 58 hours. On his way to Los Alamos, he took the wrong turning at Albuquerque because of a congenital inability to tell left from right. Mistaking him for her beau 'Little Boy', the 18-year-old receptionist of his hotel has just tried to go to bed with him.

Thus, in Clever Dick, playwright-director Crispin Whittell lays out the ingredients for a classic farce. But the sobriquets of two characters reveal a deadly serious setting: Little Boy and Fat Man were the nemeses of Hiroshima and Nagasaki. One month after Whittell's imagined encounter in a New Mexico hotel room, the first atomic bomb is to be tested.

Hence Feynman, played by Adrian Rawlins with a nervous, nerdy energy that contrives to make his slight build seem lanky. His busy hands conduct to a score with some diverting passages ("So he knows a lot of Communists. I know a lot of women, but that doesn't make mea woman ${ }^{\text {}}$ ) and frenetic, slapstick moments - topped by a spectacular re-entry for Fat Man, amply portrayed by Corey Johnson, that literally brings the house down.

But ultimately this farrago is, like that ceiling, a false plasterboard mishmash. Its profound periods are not deep enough nor its farcical moments sustained enough to carry the audience, which is only truly captivated by a moment of pathos towards the end when Feynman reveals the real reason for his confusion: the death, the evening before, of his wife from tuberculosis. Science enters in the second half only in a shampoo-ad-style 'here's the science bit' as a fig-leaf for the play's intellectual flaccidity. Feynman, rigorous scientist and, above all, great communicator of modern physics, would, one suspects, not have been pleased.
Indeed, what is Feynman doing here? He is pitched - as a participant in the Manhattan project that developed the atom bomb - as the voice of nuanced moral doubt against the dumb certitude of the gung-ho Stokes with his unshakeable faith in God and the gun (an intended contemporary resonance). But this is a role that Feynman never played: his principal extramural contribution to the Manhattan project lay not in breast-beating but bongo-beating and the apocryphal cracking of every safe containing nuclear secrets on the Los Alamos site. He was ever, in Freeman Dyson's words, "half genius and half buffoon". As he said in a 1981 interview: "What I did — immorally, I would say - was to not remember the reason that I said I was doing it, so that when ... Germany was defeated, not the singlest thought came to my mind ... I simply didn't think, okay?”

Michael Frayn's Copenhagen left a great appetite for plays that deal with the interface of science and morality. This is Whittell's second foray onto such territory, following his generally well-received 2003 play Darwin in Malibu. The safe-cracking, wisecracking womanizer Feynman is a headline-grabbing front man for a second attempt. In this case the result is, charitably put, confused.

Richard Webb is the physical-sciences News and Views editor at Nature.

\section{On Seeing: Things Seen, Unseen and \\ Obscene \\ by F. Gonzalez-Crussi \\ Overlook/Duckworth: 2006. 224 pp. \\ $\$ 24.95 / £ 14.99$}

\section{Richard Gregory}

Frank Gonzalez-Crussi is a pathologist, well versed in how we see, although here he focuses on what we see, and on what, for obscure reasons, are rejected by eye and mind. This disportment in art and medicine is rewarding thanks to the power of the writing to carry the reader safely to "things seen, unseen and obscene". These include the body, viewed from inside and outside with a medical gaze; French literature and history (with a hilarious account of the start of the Revolution triggered by

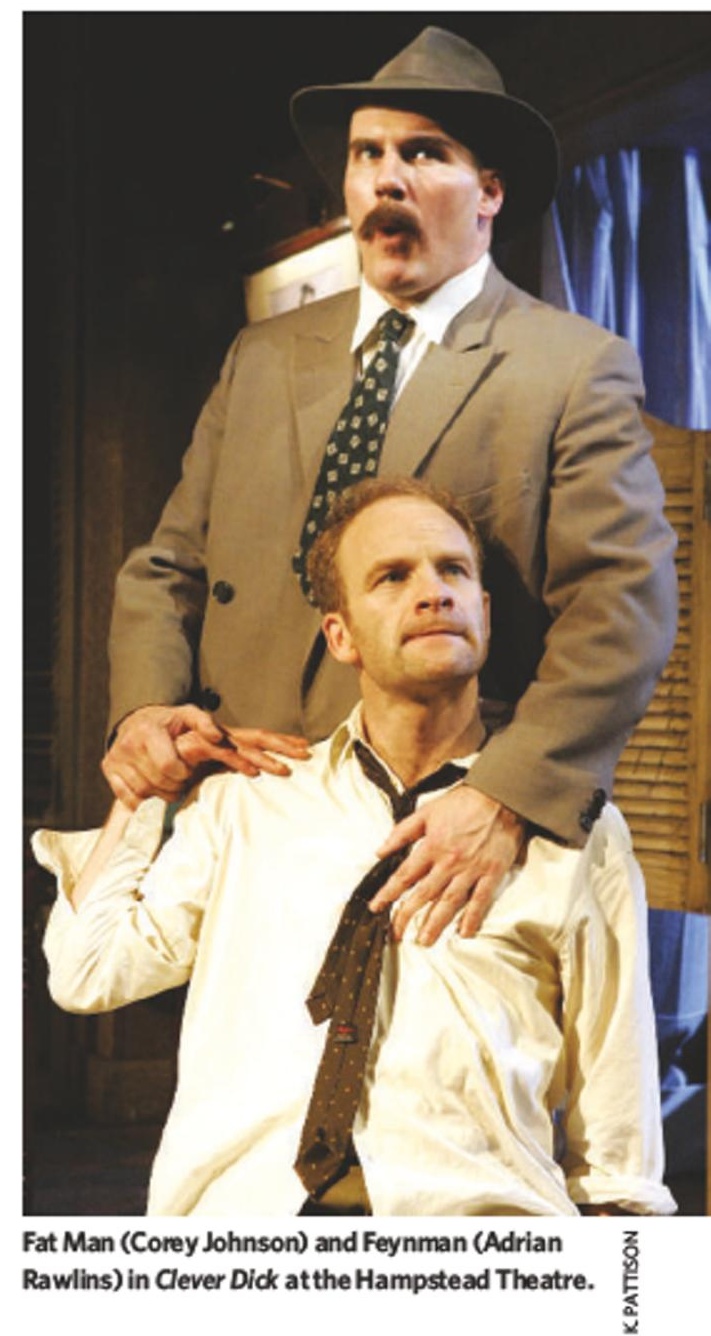

The eye of the beholder

a pair of royalist voyeurs); belief; and sin. A principal theme is the attraction and repulsion of the anatomical focus of femininity to the male eye, which induces a fascinated fear, rather like standing on the edge of cliff.

Gonzalez-Crussi suggests reasons for why anatomy was so slow to develop as a science, including the inability to make effective use of detailed knowledge before anaesthetics. But has a lack of rapid use impeded other sciences? If it is inhibition associated with prurience that held back the study of anatomy, it is unfortunate that this book was not available centuries ago. It can be enjoyed for its broad learning, and its broad humour.

Richard Gregory is in the Department of Experimental Psychology, University of Bristol, Bristol BS81HH, UK. 